Article

\title{
Evaluation of Ethanol Extract of Moringa oleifera Lam. As Acaricide against Oligonychus punicae Hirst (Trombidiformes: Tetranychidae)
}

\author{
Rapucel Tonantzin Quetzalli Heinz-Castro ${ }^{1}$, Roberto Arredondo-Valdés ${ }^{2}$, Salvador Ordaz-Silva ${ }^{3}$,

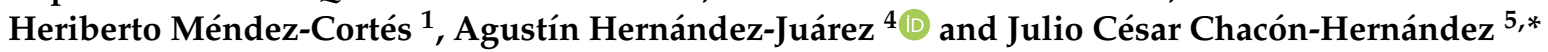 \\ 1 Faculty of Agronomy and Veterinary, Universidad Autónoma de San Luis Potosí, Soledad de Graciano \\ Sánchez 78321, San Luis Potosí, Mexico; rapucel.heinz@uaslp.mx (R.T.Q.H.-C.); \\ heriberto.mendez@uaslp.mx (H.M.-C.) \\ 2 Faculty of Chemical Science, Universidad Autónoma de Coahuila, Saltillo 25280, Coahuila, Mexico; \\ r-arredondo@uadec.edu.mx \\ 3 Faculty of Business and Engineering San Quintín, Universidad Autónoma de Baja California, \\ San Quitín 22930, Baja California, Mexico; salvador.ordaz.silva@uabc.edu.mx \\ 4 Parasitology Department, Universidad Autónoma Agraria Antonio Narro, Saltillo 25315, Coahuila, Mexico; \\ chinoahj14@hotmail.com \\ 5 Institute of Applied Ecology, Universidad Autónoma de Tamaulipas, Victoria City 87019, Tamaulipas, Mexico \\ * Correspondence: jchacon@docentes.uat.edu.mx
}

check for

updates

Citation: Heinz-Castro, R.T.Q.;

Arredondo-Valdés, R.; Ordaz-Silva, S.;

Méndez-Cortés, H.; Hernández-Juárez,

A.; Chacón-Hernández, J.C. Evaluation of Ethanol Extract of Moringa oleifera

Lam. As Acaricide against Oligonychus punicae Hirst (Trombidiformes:

Tetranychidae). Insects 2021, 12, 476.

https://doi.org/10.3390/

insects12050476

Received: 23 April 2021

Accepted: 11 May 2021

Published: 20 May 2021

Publisher's Note: MDPI stays neutral with regard to jurisdictional claims in published maps and institutional affiliations.

Copyright: (c) 2021 by the authors. Licensee MDPI, Basel, Switzerland. This article is an open access article distributed under the terms and conditions of the Creative Commons Attribution (CC BY) license (https:/ / creativecommons.org/licenses/by/ $4.0 /)$.
Simple Summary: Avocado bronze mite (ABM), Oligonychus punicae Hirst (Acari: Tetranychidae) is one of the most economically important pests in avocado cultivars. Its feeding causes major damage, defoliation and fruit abortion. Control measures of ABM are performed mainly through the use of synthetic acaricides. Alternative control strategies for ABM with a low environmental impact are necessary. The aim of this research was to assess the effect of different concentrations $(0.1,0.5,1,5,10,15$ and $20 \%(v / v))$ of ethanolic extract from Moringa oleifera leaves against adult ABM females. Mites treated with 0.1 and $20 \%(v / v)$ of the extract showed mortality of $0.00 \%$ and $46.67 \%, 6.67 \%$ and $86.67 \%, 13.70 \%$ and $96.67 \%$, at 24,48 and $72 \mathrm{~h}$, respectively, compared to the control group. The oviposition and eggs hatch, as well as ABM feeding rates, depended on the extract concentration, which led to a reduction in the growth rate. The M. oleifera leaves ethanolic extract has potential to control O. punicae.

Abstract: Tetranychidae family is a major group of mites causing serious damage in agricultural, vegetable and ornamental crops. Avocado bronze mite (ABM), Oligonychus punicae Hirst (Acari: Tetranychidae) causes major crop damage, defoliation and fruit abortion. At present, the control of this mite depends mainly on agrochemicals. Therefore it is necessary to find alternatives to synthetic pesticides that can help minimize environmental impact and health risks for the consumers. The aim of this research was to assess the effect of different concentrations $(0.1,0.5,1,5,10,15$ and $20 \%(v / v))$ of ethanolic extract of Moringa oleifera leaves against adult ABM females. Mites treated with 0.1 and $20 \%$ $(v / v)$ of the extract showed mortality of $0.00 \%$ and $46.67 \%, 6.67 \%$ and $86.67 \%, 13.70 \%$ and $96.67 \%$, at 24,48 and $72 \mathrm{~h}$, as compared to the control treatment, respectively. The number of eggs laid and hatch, as well as ABM feeding rates, depended on the extract concentration, which led to a reduction in the growth rate. M. oleifera leaf ethanolic extract has potential to control O. punicae.

Keywords: avocado bronze mite; oviposition; hatched eggs; damage; feed intake; mortality; residuality

\section{Introduction}

Tetranychidae include around 1326 identified species. They are a major group of mites, which feed from agricultural, vegetable and ornamental crops. More than one hundred species are considered pests and around 10 of them are important [1]. Most of these pest mites belong 
to two genera, Tetranychus Dufour and Oligonychus Berlese [2]. Two hundred and thirteen (213) Oligonychus species have been found feeding on perennial grasses, ornamental bushes and trees [3]. Avocado bronze mite (ABM), Oligonychus punicae Hirst (Acari: Tetranychidae), is native to Mexico and feeds on 34 plant species. It is distributed in Neotropical countries such as Brazil, Colombia, Costa Rica, Cuba, El Salvador, Honduras, Mexico, Nicaragua, Panama and Venezuela [1,3,4]. In Mexico, ABM is a major pest affecting several avocado cultivars (Persea americana L.). High populations of these mites cause defoliation, leading to sunscalds in fruits, causing fruit drops, due to fruit-setting abortion, providing lower yields [4,5]. Chemical control is the main ABM management method. However, ABM's short life cycle and high fertility cause them to develop resistance to acaricides very quickly $[4,5]$. Furthermore, synthetic pesticide residues can cause harmful effects on human health and have a high environmental impact. For these reasons, there is an urgent need to develop safe, ecological techniques [6].

Moringa tree, Moringa oleifera Lam. (Moringaceae), grows in tropical and subtropical countries and all the tree parts are used for different purposes, including human and animal health, as well as traditional medicine. Different parts of $M$. oleifera have been studied, in particular the leaves, because of its wide range of applications and properties. Literature contains reports stating that Moringa leaves have several bioactive compounds such as vitamins, carotenoids, polyphenols, phenolic acids, flavonoids, alkaloids, glucosinolates, isothiocyanates, tannins, saponins, oxalates and phytates [7]. Several researchers have reported that $M$. oleifera has pest control properties. The leaf powder from M. oleifera has anti-egg-laying activity over Callosobruchus maculatus F. (Coleoptera: Chrysomelidae) and Tribolium castaneum Herbst (Coleoptera: Tenebrionidae) [8]. Likewise, M. oleifera oil has anti-feeding properties over Spodoptera littoralis Boisd larvae (Lepidoptera: Noctuidae) [9] and S. frugiperda Walker (Lepidoptera: Noctuidae) [10]. Furthermore, the lectins in $M$. oleifera seeds have larvicidal effect over the developing instars of Aedes aegypti mosquito L. (Diptera: Culicidae) [11] and over the Mediterranean flour moth Ephestia kuehniella Zeller (Lepidoptera: Pyralidae) [12]. The aim of this research was to assess the effects of ethanolic extract of M. oleifera leaves on mortality, food intake, oviposition, hatching and growth rate of $O$. punicae at different concentrations, since such effects may serve as useful basis for a compound in O. punicae's integrated management program

\section{Materials and Methods}

\subsection{Colony}

The ABM females used in this research work came from a colony of plants infested by Pithecellobium dulce (Roxb.) Benth. (Fabaceae) in Ciudad Victoria, Tamaulipas $\left(23^{\circ} 44^{\prime} 38.4^{\prime \prime} \mathrm{N}, 99^{\circ} 9^{\prime} 57.599^{\prime \prime} \mathrm{O}, 329 \mathrm{msnm}\right)$ [13]. In order to increase ABM population, adult females and males were placed on bean plants (Phaseolus vulgaris L. (Fabaceae)), under greenhouse conditions $29 \pm 4{ }^{\circ} \mathrm{C}$ and $60 \pm 15 \%$ relative humidity (RH).

\subsection{Preparation of the Plant Material and the Extract}

We collected visibly clean leaves of M. oleifera in the Applied Ecology Institute at Universidad Autonoma de Tamaulipas. The leaves were dried in a conventional oven (Quincy lab, Chicago, IL, USA model 20GCE-LT) at $60^{\circ} \mathrm{C}$ for three days, until obtaining a consistent weight. The sample was grounded (Miller CUISINART, Stamford, CT, USA, model DBM-8) until forming particles of $1 \mathrm{~mm}$ [14]. The powder was stored in dark bottles at ambient temperature in preparation for the extraction.

Fourteen grams of the dry homogenized $M$. oleifera leaf powder was blended with $200 \mathrm{~mL}$ of absolute ethanol at ambient temperature. This was done during three days with the aid of a stirrer in total darkness. The blend was filtered with Whatman No. 1. Filter paper. The extract was placed in a rotary evaporator (IKA-RV 10 digital V, Staufen Baden-Wurtemberg, Germany) to evaporate the solvent, at temperatures lower than $40{ }^{\circ} \mathrm{C}$ and under reduced pressure. Finally, the remaining ethanol was evaporated placing the flask on the kiln drier until obtaining a consistent weight (three days) [15]. The extract 
was scraped off and stored into Eppendorf tubes and kept in a freezer at $-10{ }^{\circ} \mathrm{C}$, before conducting the bioassays.

\subsection{Phytochemical Extract Analysis}

We performed the ethanolic extract analysis of $M$. oleifera in order to do the qualitative detection tests of phytochemicals. The test included alkaloids (Dragendorff \& Sonheschain reagent); phenols (Iron Chloride test $\mathrm{FeCl} 3$ ); carbohydrates (Molisch reagent); carotenoids $\left(\mathrm{H}_{2} \mathrm{SO}_{4}\right.$ and $\mathrm{FeCl}_{3}$ reagents); coumarins (Erlich reagent); flavonoids (Shinoda reagent and $\mathrm{NaOH}$ at $1 \%$ ); free reducing sugar (Fehling and Benedict reagent); cyanogenic glycosides (Grignard reagent); purines ( $\mathrm{HCl}$ test); quinones $\left(\mathrm{NH}_{4} \mathrm{OH}\right.$ and $\mathrm{H}_{2} \mathrm{SO}_{4}$ reagents by anthraquinone, and Börntraguer test by benzoquinone); saponins (foam test, Bouchard reagent for steroid saponins and Rosenthaler reagent); terpenoids $\left(\mathrm{Ac}_{2} \mathrm{O}\right.$ reagent); soluble starch ( $\mathrm{KOH}$ and $\mathrm{H}_{2} \mathrm{SO}_{4}$ test) and tannins ( $\mathrm{FeCl}_{3}$ reagent and ferrocyanide) [16-18].

\subsection{Experimental Design}

We used the sand technique described by Ahmadi [19], with a slightly modification. Bean discs of $2.5 \mathrm{~cm}$ in diameter were cut and placed on water-soaked cotton, with the underside facing up. A disc was placed inside a $5 \mathrm{~cm}$ wide Petri dish, each disc had 10 adult $\mathrm{ABM}$ females with one day age. The experiment was done under laboratory conditions at $27 \pm 1{ }^{\circ} \mathrm{C}, 70-80 \%$ relative humidity (RH) and a photoperiod of $12: 12$ (light:darkness). The bean leaf discs were split at random in eight groups: a control group and seven treatment groups, one per each extract concentration. A bean leaf disc was the replicate. We had three replicates per group. Ten mite females were placed on each bean leaf disc and they were sprayed two times $(0.7 \pm 0.1 \mathrm{~mL}$ per spray) with each concentration. A manual sprayer (Truper ${ }^{\circledR}$ Model 14687 Ciudad de Victoria, Mexico) was used to apply M. oleifera extract at different concentrations $[0.1,0.5,1,5,10,15,20 \% v / v$ (ethanol/water)]. The control treatment was sprayed with distilled water only. We recorded the number of dead mites at 24,48 and $72 \mathrm{~h}$. Mites with ataxia (active, apparently messy movement) were considered dead, as well as mites lying on their backs, legs up, or without moving. We also counted the number of eggs laid and we observed the damage caused by ABM. ABM eggs' hatching determined the residual effect, based on the number of eggs laid at $24 \mathrm{~h}$. In average, ABM eggs hatch between 4.4 and 4.7 days $27 \pm 2{ }^{\circ} \mathrm{C}$ with a photoperiod of $12: 12 \mathrm{~h}$ light:dark and $80 \pm 10 \% \mathrm{RH}$, on different host plants [20]. Therefore, five days after applying the concentrations, we recorded the number of eggs hatched. The eggs that did not hatch within that time were considered non-viable. The counts and feeding observations were conducted with a dissection microscope (UNICO Stereo and Zoom Microscopes ZM180, Princeton, NJ, USA).

\subsection{Oligonychus punicae Mortality Essay}

We corrected the mortality data using Abbott's formula on the control group [21].

$$
\mathrm{MC}=\left[\left(\% \mathrm{M}_{\mathrm{T}}-\% \mathrm{M}_{\mathrm{C}}\right) /\left(100-\% \mathrm{M}_{\mathrm{C}}\right)\right] \times 100
$$

where $\% \mathrm{M}_{\mathrm{T}}$ is the mortality percentage in the treated group and $\% \mathrm{M}_{\mathrm{C}}$ is the mortality percentage in the control group.

\subsection{Oligonychus punicae Oviposition and Hatched Eggs Essay}

We used Kramer and Mulla [22] formula to determine the oviposition activity percentage (OAP) in each concentration.

$$
\mathrm{OAP}=\left[\left(\mathrm{N}_{\mathrm{T}}-\mathrm{N}_{\mathrm{C}}\right) /\left(\mathrm{N}_{\mathrm{T}}+\mathrm{N}_{\mathrm{C}}\right)\right] \times 100
$$

where $\mathrm{N}_{\mathrm{C}}$ is the number of eggs in the control group and $\mathrm{N}_{\mathrm{T}}$ is the number of eggs in the treated group with the extract. The percentage values ranged between +100 and -100 . The positive values indicate that we observed more eggs laid in the treatment than in the 
control group (showing that the extract stimulated egg-laying activity). In contrast, more eggs laid in the control group than in the treatment resulted in a negative OAP, indicating that the extract inhibited the egg-laying activity.

In order to measure the residual effect of the extract on $\mathrm{ABM}^{\prime}$ 's egg hatching, we used the criterion of Kramer and Mulla [22] formula. The negative values indicate that there were a larger number of eggs hatched in the control group than in the group of treated mites. This shows that the residual effect of the extract inhibited egg-hatching, or that the eggs take longer to develop. The positive values indicate that there is a larger number of eggs hatched in the group of treated mites than in the control group, showing that the extract stimulated hatching in ABM eggs, or that the development time is less than 4.4 or 4.7 days [20].

\subsection{Oligonychus punicae Anti-Feeding}

We assessed the anti-feeding effect through the inhibition percentage of feed intake by $\mathrm{ABM}$ in the bean leaf discs, as compared to the control treatment. At $72 \mathrm{~h}$, we classified the symptoms observed in the bean leaf discs according to an ordinal scale developed by Hussey and Parr [23] and Nachman and Zemek [24]. We converted them into percentages: $0=0 \%$ damage ( $w$ ith no feeding damage), $1=1-20 \%, 2=21-40 \%, 3=41-60 \%, 4=61-80 \%$ and $5=81-100 \%$ of feeding damage (dense marks, or wilting, after eating all the bean disc). We used the criterion of Kramer and Mulla [22] formula to measure the females' food intake. The positive values show that there was more damage in the treatment group than in the control group, indicating that the treatment promoted feeding. The negative values represent more severe damage to the control group than to the treatment group, indicating that feeding was inhibited in the treatment group [25].

\subsection{Oligonychus punicae Growth Population}

We used the growth rate $\left(r_{i}\right)$ as a parameter to determine the effect of the extract on ABM population.

$$
\mathrm{r}_{\mathrm{i}}=\left(\left(\mathrm{N}_{\mathrm{f}} / \mathrm{N}_{0}\right)\right) / \Delta \mathrm{t}
$$

where $\mathrm{N}_{0}$ is the initial number of individuals (10 adult females by replicate); $\mathrm{N}_{\mathrm{f}}$ is the final number of individuals (adult surviving females plus the eggs laid at the end of the bioassay) and $\Delta \mathrm{t}$, which is the number of days elapsed from the beginning until the end of the bioassay (equal to 3 days). Positive values of $r_{i}$ indicate a growing population. The negative values indicate a declining population, and $r_{i}=0$ indicates a stable population [26,27].

\subsection{Statistical Analysis}

Mortality percentage, the number of laid eggs, eggs hatched, the percentage of feeding damage and the growth rate were statistically analyzed using the variance analysis (ANOVA) and the means were separated by post-hoc Tukey's multiple range comparison test $(p \leq 0.05)$. Probit analysis was used to estimate the lethal concentration $\left(\mathrm{LC}_{50(90)}\right)$, causing 50(90)\% mortality in O. punicae population, with confidence intervals of $95 \%$ (CI95) [28]. SAS/STAT program was used in every analysis [29].

\section{Results}

\subsection{Phytochemical}

The ethanolic extract of M. oleifera leaves has several groups of secondary metabolites, such as phenols, alkaloids, flavonoids, tannins, saponins, carbohydrates and quinones (Table 1). 
Table 1. Qualitative phytochemical ("+" = present; "-“ = absent) screening of ethanolic extract of Moringa oleifera leaves.

\begin{tabular}{|c|c|c|c|c|c|}
\hline Bioactive Compound & & Test & Bioactive Compound & & Test \\
\hline \multirow{2}{*}{ Alkaloids } & \multirow{2}{*}{+} & Dragendorff's & \multirow{2}{*}{ Flavonoids } & \multirow{2}{*}{+} & Shinoda for flavanone's \\
\hline & & Sonheschain's & & & $\begin{array}{c}\mathrm{NaOH} \text { at } 1 \% \text { for flavanone's } \\
\text { or Xanthone }\end{array}$ \\
\hline & & $\mathrm{FeCl}_{3}$ for gallic acid & \multirow{3}{*}{ Quinones } & \multirow{3}{*}{+} & $\mathrm{NH}_{4} \mathrm{OH}$ for Anthraquinone \\
\hline Tannins & + & Ferrocyanide for phenols & & & $\mathrm{H}_{2} \mathrm{SO}_{4}$ for Anthraquinone \\
\hline Carbohydrates & + & Molisch's & & & $\begin{array}{l}\text { Bröntraguer's for } \\
\text { benzoquinone }\end{array}$ \\
\hline Carotenoids & + & $\mathrm{H}_{2} \mathrm{SO}_{4}$ and $\mathrm{FeCl}_{3}$ reagents & Soluble starch & + & $\mathrm{KOH}$ and $\mathrm{H}_{2} \mathrm{SO}_{4}$ \\
\hline \multirow{2}{*}{ Sugar reducers } & \multirow{2}{*}{+} & Fehling's & Coumarins & + & Erlich's \\
\hline & & Benedict's & Cyanogenic glycosides & + & Grignard's \\
\hline \multirow{3}{*}{ Saponins } & + & $\begin{array}{c}\text { Bouchard for steroidal } \\
\text { saponins }\end{array}$ & Terpenoids & - & $\mathrm{Ac}_{2} \mathrm{O}$ \\
\hline & - & Foam & Purines & - & $\mathrm{HCl}$ \\
\hline & - & Rosenthaler & Phenols & + & $\mathrm{FeCl}_{3}$ \\
\hline
\end{tabular}

\subsection{Acaricidal Effect of M. oleifera Extract on Oligonychus punicae}

\subsubsection{Mortality}

We evaluated the effect of seven concentrations of ethanolic extract of $M$. oleifera leaves against adult females of ABM (Table 2). At 24, 48 and $72 \mathrm{~h}$ after extract application there was a significant effect on the number of $\mathrm{ABM}$ female $(\mathrm{F}=64.81 ; \mathrm{df}=6,14 ; p<0.0001$; $\mathrm{F}=119.56 ; \mathrm{df}=6,14 ; p<0.0001 ; \mathrm{F}=163.82 ; \mathrm{df}=6,14 ; p<0.0001)$, respectively. At $24 \mathrm{~h}$, mortality ranged between $0.00 \%(0.1 \%(v / v))$ and $70.00 \%(20.0(v / v))$, by $48 \mathrm{~h}$, between 3.33 $(0.1 \%(v / v))$ and $83.33 \%(20.0(v / v))$, and by $72 \mathrm{~h}$ between $10.37(0.1 \%(v / v))$ and $96.67 \%$ $(20.0(v / v))$, compared to the control treatment (Table 2). Lethal concentration $\mathrm{LC}_{50(90)}$ was $7.99(15.68) \%(v / v)$; meaning, that only $7.99(15.68) \%(v / v)$ are required to kill $50(90) \%$ of O. punicae's population (Table 2). The results showed that the percentage of O. punicae mortality increased as the extract concentration increased.

Table 2. Effect of ethanolic extract of Moringa oleifera leaves at different concentrations on Oligonychus punicae females.

\begin{tabular}{cccc}
\hline Concentration (\%) & \multicolumn{3}{c}{ Average Mortality ( \pm SE) Percentage * } \\
\hline & $\mathbf{2 4}$ & $\mathbf{4 8}$ & $\mathbf{7 2}$ \\
\hline 0.1 & $0.00 \pm 0.00 \mathrm{~d}$ & $3.33 \pm 3.33 \mathrm{~d}$ & $10.37 \pm 0.37 \mathrm{~d}$ \\
0.5 & $3.33 \pm 0.33 \mathrm{~d}$ & $10.00 \pm 0.00 \mathrm{c}$ & $17.04 \pm 2.96 \mathrm{~d}$ \\
1 & $10.00 \pm 0.00 \mathrm{~d}$ & $16.67 \pm 0.33 \mathrm{c}$ & $20.37 \pm 5.46 \mathrm{~cd}$ \\
5 & $16.67 \pm 3.33 \mathrm{~d}$ & $23.33 \pm 0.33 \mathrm{c}$ & $31.11 \pm 1.11 \mathrm{c}$ \\
10 & $36.67 \pm 3.33 \mathrm{c}$ & $63.33 \pm 0.33 \mathrm{~b}$ & $72.59 \pm 8.12 \mathrm{~b}$ \\
15 & $53.33 \pm 3.33 \mathrm{~b}$ & $76.67 \pm 0.33 \mathrm{ab}$ & $89.63 \pm 0.37 \mathrm{a}$ \\
20 & $70.00 \pm 5.77 \mathrm{a}$ & $83.33 \pm 0.33 \mathrm{a}$ & $96.67 \pm 3.33 \mathrm{a}$ \\
$\mathrm{LC}_{50}\left(\mathrm{CI}_{95}\right)$ & $\mathrm{LC}_{90}\left(\mathrm{CI}_{95}\right)$ & $\mathrm{b} \pm \mathrm{EE}$ & $\chi^{2}$ \\
7.99 & 15.68 & $7.50 \pm 0.94$ & $63.50 * * *$ \\
$(6.87-8.95)$ & $(13.86-18.63)$ & & \\
\hline
\end{tabular}

* Mortality corrected using Abbot's formula (Abbott 1925). ${ }^{* *}$ Means values and \pm standard error (SE) is presented. Different letters indicate significant differences. LC: Lethal concentration killing 50(90) \% of ABM's population. CI: Confidence interval at $95 \%$. b: slope \pm standard error. $\chi^{2}$ : Chi-square value. ${ }^{* * *}$ Level of significance $p<0.0001$.

\subsubsection{Oviposition}

The number of $O$. punicae eggs laid, varied significantly at 24,48 and $72 \mathrm{~h}(\mathrm{~F}=940.69$; $\mathrm{df}=7,16 ; p<0.0001 ; \mathrm{F}=1360.56 ; \mathrm{df}=7,16 ; p<0.0001 ; \mathrm{F}=2668.89 ; \mathrm{df}=7,16 ; p<0.0001)$, respectively. Mites treated with $0.1 \%$ and $20 \%(v / v)$ inhibited egg-laying by $2.54 \%$ and $94.69 \%, 2.92 \%$ and $94.45 \%, 3.63 \%$ and $95.26 \%$ at 24,48 and $72 \mathrm{~h}$, respectively, as compared to the control treatment. The growth rate of the ABM was also statistically significant 
among the treatments, versus the control group $(\mathrm{F}=1311.75 ; \mathrm{gl}=7,16 ; p<0.0001)$ (Table 3 ) and it decreased according to the concentration.

Table 3. Effect of ethanolic extract of Moringa oleifera leaves on oviposition and growth rate of Oligonychus punicae.

\begin{tabular}{|c|c|c|c|c|c|c|c|}
\hline $\begin{array}{c}\text { Concentration } \\
\%(v / v)\end{array}$ & $\begin{array}{c}\text { Average } \\
\text { Number of } \\
\text { Eggs } \pm \text { SE }\end{array}$ & OAP (\%) & $\begin{array}{c}\text { Average } \\
\text { Number of } \\
\text { Eggs } \pm \text { SE }\end{array}$ & OAP (\%) & $\begin{array}{c}\text { Average } \\
\text { Number of } \\
\text { Eggs } \pm \text { SE }\end{array}$ & OAP (\%) & Growth Rate \pm SE \\
\hline & \multicolumn{2}{|c|}{$24 h^{*}$} & \multicolumn{2}{|c|}{$48 \mathrm{~h}$} & \multicolumn{2}{|c|}{$72 \mathrm{~h}$} & \\
\hline Control & $61.33 \pm 1.533 \mathrm{a}$ & & $93.33 \pm 3.51 \mathrm{a}$ & & $109.67 \pm 1.53 \mathrm{a}$ & & $0.8267 \pm 0.00 \mathrm{a}$ \\
\hline 0.1 & $58.33 \pm 3.06 \mathrm{a}$ & $-2.54 \pm 2.27$ & $88.00 \pm 1.00 \mathrm{~b}$ & $-2.92 \pm 1.31$ & $102.00 \pm 2.65 b$ & $-3.63 \pm 1.98$ & $0.8000 \pm 0.01 \mathrm{~b}$ \\
\hline 0.5 & $47.00 \pm 1.00 \mathrm{~b}$ & $-13.23 \pm 0.97$ & $72.67 \pm 2.52 c$ & $-12.45 \pm 0.37$ & $81.67 \pm 1.53 c$ & $-14.64 \pm 1.07$ & $0.7300 \pm 0.01 \mathrm{c}$ \\
\hline 1 & $30.00 \pm 1.00 \mathrm{c}$ & $-34.31 \pm 1.14$ & $37.67 \pm 1.53 \mathrm{~d}$ & $-42.46 \pm 3.19$ & $46.67 \pm 1.53 \mathrm{~d}$ & $-40.30 \pm 1.75$ & $0.5633 \pm 0.01 \mathrm{c}$ \\
\hline 5 & $28.00 \pm 1.00 \mathrm{c}$ & $-37.30 \pm 2.59$ & $31.67 \pm 1.53 \mathrm{e}$ & $-49.34 \pm 0.61$ & $40.33 \pm 0.58 \mathrm{e}$ & $-46.22 \pm 0.39$ & $0.5200 \pm 0.00 \mathrm{~d}$ \\
\hline 10 & $4.33 \pm 0.58 \mathrm{~d}$ & $-86.83 \pm 1.33$ & $5.33 \pm 0.58 \mathrm{f}$ & $-89.16 \pm 1.45$ & $9.00 \pm 1.00 \mathrm{f}$ & $-84.83 \pm 1.75$ & $0.0500 \pm 0.04 \mathrm{~d}$ \\
\hline 15 & $2.33 \pm 0.58 \mathrm{~d}$ & $-92.66 \pm 1.89$ & $5.33 \pm 0.58 \mathrm{f}$ & $-89.16 \pm 1.45$ & $9.00 \pm 1.00 \mathrm{f}$ & $-84.83 \pm 1.75$ & $-0.0033 \pm 0.03 \mathrm{e}$ \\
\hline 20 & $1.67 \pm 0.58 \mathrm{~d}$ & $-94.69 \pm 1.89$ & $2.67 \pm 0.58 \mathrm{f}$ & $-94.45 \pm 1.19$ & $2.67 \pm 0.58 \mathrm{~g}$ & $-95.26 \pm 0.95$ & $-0.4000 \pm 0.00 \mathrm{e}$ \\
\hline
\end{tabular}

* Means values and \pm standard error (SE) is presented. Different letters indicate significant differences $(p<0.05$; ANOVA and Tukey's HSD test). OAP, percentage of oviposition activity compared to control.

\subsubsection{Eggs Viability}

The percentage of eggs hatched at the fifth day was statistically significant $(\mathrm{F}=881.36$; $\mathrm{df}=7,16 ; p<0.0001$ ). The extract concentrations of $0.1 \%$ and $20.0 \%$ caused a residual effect, leading to a decrease in the number of eggs hatched, ranging between $14.90 \%$ and $100.00 \%$, as compared to the control treatment (Table 4).

Table 4. Residual effect of ethanolic extract of Moringa oleifera leaves on Oligonychus punicae eggs (mean \pm SE) $(\%)$.

\begin{tabular}{ccc}
\hline Concentration & Hatched Eggs * & Reduction of Viable Eggs \\
\hline Control & $55.33 \pm 1.53 \mathrm{a}$ & \\
0.1 & $41.00 \pm 2.00 \mathrm{~b}$ & $-14.90 \pm 2.30$ \\
0.5 & $23.33 \pm 2.08 \mathrm{c}$ & $-42.57 \pm 2.93$ \\
1 & $9.67 \pm 1.15 \mathrm{~d}$ & $-70.25 \pm 3.57$ \\
5 & $3.67 \pm 0.58 \mathrm{e}$ & $-87.60 \pm 1.64$ \\
10 & $0.00 \pm 0.00 \mathrm{f}$ & $-100 \pm 0.00$ \\
15 & $0.00 \pm 0.00 \mathrm{f}$ & $-100 \pm 0.00$ \\
20 & $0.00 \pm 0.00 \mathrm{f}$ & $-100 \pm 0.00$
\end{tabular}

${ }^{*}$ Means values and \pm standard error (SE) is presented. Different letters indicate significant differences $(p<0.05$; ANOVA and Tukey's HSD test).

\subsubsection{Food Intake}

The damage percentage was significantly different among the treatments, at 24,48 and $72 \mathrm{~h}(\mathrm{~F}=70.66 ; \mathrm{df}=7,16 ; p<0.0001 ; \mathrm{F}=121.95 ; \mathrm{df}=7,16 ; p<0.0001 ; \mathrm{F}=220.57 ; \mathrm{df}=7$, $16 ; p<0.0001)$, respectively. Feeding activity of ABM females treated with $0.1 \%$ to $20 \%$ $(v / v)$ of $M$. oleifera extract was inhibited by $4.37 \%$ to $80.16 \%, 5.12 \%$ to $78.95 \%$ and $4.71 \%$ to $83.57 \%$ at 24,48 and $72 \mathrm{~h}$, respectively (Table 5 ).

Table 5. Effects of ethanolic extract of Moringa oleifera leaves on Oligonychus punicae feeding rate.

\begin{tabular}{|c|c|c|c|c|c|c|}
\hline $\begin{array}{c}\text { Concentration } \\
\%(v / v)\end{array}$ & $\begin{array}{l}\text { Average Damage } \\
(\%) \pm \text { SE }\end{array}$ & Food Intake (\%) $\pm \mathrm{SE}$ & $\begin{array}{l}\text { Average Damage } \\
(\%) \pm \mathrm{SE}\end{array}$ & Food Intake (\%) & $\begin{array}{c}\text { Average Damage } \\
(\%) \pm \mathrm{SE}\end{array}$ & Food Intake (\%) $\pm \mathrm{SE}$ \\
\hline & \multicolumn{2}{|c|}{$24 \mathrm{~h}$ * } & \multicolumn{2}{|c|}{$48 \mathrm{~h}$} & \multicolumn{2}{|c|}{$72 \mathrm{~h}$} \\
\hline Control & $12.00 \pm 0.58 \mathrm{a}$ & & $17.00 \pm 0.58 \mathrm{a}$ & & $26.00 \pm 0.58 \mathrm{a}$ & \\
\hline 0.1 & $11.00 \pm 0.58 \mathrm{ab}$ & $-4.33 \pm 0.22$ & $15.33 \pm 0.33 a$ & $-5.12 \pm 0.95$ & $23.67 \pm 0.67 a$ & $-4.71 \pm 0.71$ \\
\hline 0.5 & $9.33 \pm 0.33 b$ & $-12.44 \pm 1.27$ & $12.00 \pm 0.58 \mathrm{~b}$ & $-17.24 \pm 3.98$ & $20.00 \pm 0.58 b$ & $-13.05 \pm 2.18$ \\
\hline 1 & $5.67 \pm 0.33 c$ & $-35.81 \pm 3.44$ & $9.33 \pm 0.33 c$ & $-29.06 \pm 3.08$ & $16.33 \pm 0.88 c$ & $-22.89 \pm 3.58$ \\
\hline 5 & $4.33 \pm 0.33 \mathrm{~cd}$ & $-46.81 \pm 4.73$ & $7.00 \pm 0.58 \mathrm{~cd}$ & $-41.67 \pm 4.81$ & $13.33 \pm 0.67 c$ & $-31.14 \pm 2.37$ \\
\hline 10 & $2.33 \pm 0.33 \mathrm{de}$ & $-67.52 \pm 3.94$ & $4.67 \pm 0.33 \mathrm{de}$ & $-57.02 \pm 1.59$ & $8.00 \pm 0.58 \mathrm{~d}$ & $-52.97 \pm 3.05$ \\
\hline 15 & $2.33 \pm 0.88 \mathrm{de}$ & $-67.94 \pm 11.41$ & $3.00 \pm 0.58$ ef & $-70.11 \pm 5.29$ & $3.67 \pm 0.33 \mathrm{e}$ & $-75.25 \pm 2.39$ \\
\hline 20 & $1.33 \pm 0.33 \mathrm{e}$ & $-80.16 \pm 4.42$ & $1.67 \pm 0.67 \mathrm{f}$ & $-82.26 \pm 6.92$ & $2.33 \pm 0.33 \mathrm{e}$ & $-83.57 \pm 2.15$ \\
\hline
\end{tabular}

${ }^{*}$ Means values and \pm standard error (SE) is presented. Different letters indicate significant differences ( $p<0.05$; ANOVA and Tukey's HSD test). 


\section{Discussion}

Secondary metabolites such as steroids, alkaloids, terpenoids, phenolic compounds and essential oils present in more than 2000 plant species have insecticide properties. In developed countries, a few by-products of these plants are used as botanical insecticides $[30,31]$. Botanical insecticides represent $1 \%$ of the global insecticide market $[30,31]$. In this research work, the phytochemical analysis of ethanolic extract of $M$. oleifera leaves showed the presence of several secondary metabolites, such as flavonoids, alkaloids and cyanogenic glycosides. These bioactive compounds can be useful to pest management strategies [32]. Secondary metabolites (flavonoids, alkaloids and cyanogenic glycosides) have insecticidal effects; inhibiting development as well as egg-laying and feeding rates of mites. They can also be repellent, toxic and can have anti-feeding, attractant and killing effects on several species of insects and herbivores [32].

There is no reference in literature regarding the use of $M$. oleifera leaves ethanolic extract for the control of O. punicae or any other mite species. However, the effects of other plant extracts on Oligonychus spp. have been studied and those results are similar to the results of this work. This research shows that $O$. punicae mortality rate increases in relation higher extract concentrations. Similarly, egg-hatching, egg-laying, growth rate and feeding rate decrease as concentration increases. Roy et al. [33], reported the mortality of Oligonychus coffeae Nietner (Tetranychidae: Acarina) at concentrations of $2 \%, 4 \%, 6 \%, 8 \%$ and $10 \%$ $(v / v)$ of Polygonum hydropiper L. (Polygonaceae) aqueous extract. The mortality percentage increased at $24 \mathrm{~h}(26.58 \%$ to $80.07 \%), 48 \mathrm{~h}(26.58 \%$ to $86.41 \%)$ and $72 \mathrm{~h}(26.58 \%$ to $89.92 \%)$, as compared to the control $(0.00 \%$ at 24,48 and $72 \mathrm{~h})$. Furthermore, Sarmah et al. [30] documented that aqueous extracts of Acorus calamus L. (Araceae), Clerodendrun infortunatum L. (Verbenaceae), Xanthium strumarium L. (Compositae) and Polygonum hydropiper L. (Polygonaceae) increased the mortality of O. coffeae at $24 \mathrm{~h}(6.4 \%$ to $87.7 \% ; 23.0 \%$ to $100.0 \%$; $15.6 \%$ to $87.2 \% ; 12.8 \%$ to $77.7 \%), 48$ h $(6.4 \%$ to $87.7 \% ; 23.0 \%$ to $100.0 \% ; 15.6$ to $87.2 ; 12.8 \%$ to $77.7 \%)$ and 72 h $(6.4 \%$ to $88.7 \% ; 23.0 \%$ to $100.0 \% ; 15.6 \%$ to $91.8 \% ; 12.8 \%$ to $84.2 \%)$ at concentrations ranging between $2.5 \%$ to $10 \%(w / v)$, respectively. In addition, Fetoh and Al-Shammery [34] found that the concentrations (10,100, 1000, 10,000 and 100,000 ppm) of the ethanolic extract from Demsisa (Ambrosia maritimal L. (Compositae)), Duranta, (Duranta plumeria L. (Verbenaceae)) and Cumin (Cuminum cyminum L. (Labiaceae)) caused mortality in O. afrasiaticus McGregor (39.00\% to $93.00 \%$; $33.33 \%$ to $69.00 \%$; $12.00 \%$ to $64.67 \%$ ) at $24 \mathrm{~h}$. Mamun et al. [35] reported that extracts from P. hydropiper, X. strumarium, Datura metel L. (Solanaceae), Lantana camara L. (Verbenaceae), Swietenia mahagoni (L.) Jacq. (Meliaceae) and Azadirachta indica A. Juss. (Meliaceae) cause mortality in O. coffeae. Roobakkumar et al. [36] found that the aqueous extracts of Pongam and Garlic seeds, as well as Neem seeds caused mortality of $100 \%$ and $90 \%$ of O. coffeae mites, respectively. Roy and Mukhopadhyay [37] documented a mortality rate ranging from $0.00 \%$ to $90.60 \%$ of O. coffeae adults treated with 1 to $10 \%(w / v)$ of seed aqueous extract of Melia azedarach L. (Meliaceae) at $72 \mathrm{~h}$.

In this research, the number of eggs laid by O. punicae females lowered as M. oleifera extract concentration increased. Roy et al. [31] documented that $P$. hydropiper aqueous extract reduces the egg-laying activity (1.8 to $1.4 \mathrm{eggs} /$ female) of $O$. coffeae in all the concentrations ( 2 to $10 \%(v / v)$ ) at $24 \mathrm{~h}$, as compared to the control (3.4 eggs/female). This effect became stronger with time, reducing oviposition from $1.4 \mathrm{eggs} /$ female to zero eggs/female, at concentrations of 8 and $10 \%$ in 24 to $96 \mathrm{~h}$. In addition, Roobakkumar et al. [36] reported that at $5 \%$ concentration $(w / v)$, the seed aqueous extracts of Neem, Pongam and Garlic, inhibited by 96,80 and $88 \%$ the egg-laying capacity of $O$. coffeae, as compared to the control at $96 \mathrm{~h}$. While Fetoh and Al-Shammery [34] found that the ethanolic extract of Demsisa, Duranta and Cumin decrease egg-laying activity in O. afrasiaticus at $24 \mathrm{~h}(1.3,2.20,3.30)$, $48 \mathrm{~h}(0.50,1.65,3.70)$ and $72 \mathrm{~h}(0.30,6.95,7.75 \mathrm{eggs} /$ female $)$, in contrast with the control (6.10, 6.35 and 11.66 eggs/female). Likewise, Roy and Mukhopadhyay [37] reported that the concentrations (1-10\%) of $M$. azedarachun seed aqueous extract reduced by $40 \%$ to $54 \%$ the number of eggs laid by every female of $O$. coffeae per day, compared to the control. 
In this research, the percentage of O. punicae hatched eggs decreased according to the concentration of $M$. oleifera extract, indicating that all concentrations have a residual effect, since they lowered the viability of eggs laid ranged between $14.90(0.1 \%(v / v))$ to $100.00 \%(20.0 \%(v / v))$, as compared to the control group. In this regard, Dimetry et al. [38] and Dimetry et al. [39] mentioned that secondary metabolites can directly influence over the feminine ovaries, or it can be due to the contact of the mite's cuticle with a substance present in the botanical insecticide that can alter the production of pheromones, what causes the eggs not to hatch. Fetoh and Al-Shammery [34] mentioned that chemicals present in plants could block the micropyle region of the egg, impairing gas exchange and leading to the embryo's death inside the egg. Hosny et al. [40] mentioned that adult mite females exposed to discs treated with acaricides, could be subject to partial or temporary sterilization, resulting in a lower number of eggs laid per female, per day; as well as a lower number of viable eggs, in comparison to the control. Therefore, we may conclude that $M$. oleifera causes these two effects and can be characterized by the sterilizing effect.

The ethanolic extract of $M$. oleifera inhibited ABM food intake since the first $24 \mathrm{~h}$, indicating an inverse relation between the extract concentration and the anti-feeding effect (damage). Fetoh and Al-Shammery [34] documented that concentrations at 47.6, 1102 and $8433.2 \mathrm{ppm}$ of the ethanolic extracts from Demsisa, Duranta and Cumin deter impaired by $95.33 \%$ and $97.80 \% ; 66.67 \%$ and $97.80 \% ; 55.33 \%$ and $93.33 \%$ O. afrasiaticus feeding rate on bean plants (P. vulgaris) at 24,48 and $72 \mathrm{~h}$, respectively.

El-Wakeil [41] mentioned that in order to produce a botanical insecticide at commercial scale, the source plant biomass has to be available at agricultural scale, with no seasonality if possible, unless the plant is extremely abundant in nature or it is grown already for other purposes. Moringa oleifera complies with this sustainability criterion, because Moringa trees are wild trees, but they can also be reproduced by cuttings and seed planting. The trees grow fast; in three months, they can be $3 \mathrm{~m}$ tall. When $M$. oleifera is cultivated, the leaves can be harvested at intervals ranging from 35 to 60 days [7].

\section{Conclusions}

The results show M. oleifera leaves can be used in mite control as ethanolic extract. The extract caused chronic toxicity on females and impaired hatching of O. punicae eggs, leading to lower growth rates. Furthermore, egg-laying and damage were reduced in comparison to the control. Further research is necessary, including the assessment of other M. oleifera extracts against $O$. punicae and other species of pest mites, as well as studying the extract's effect on natural enemies.

Author Contributions: Conceptualization, J.C.C.-H. and R.T.Q.H.-C.; methodology, J.C.C.-H., A.H.-J. and H.M.-C.; validation, J.C.C.-H.; formal analysis, J.C.C.-H. and S.O.-S.; resources, R.A.-V.; data curation, J.C.C.-H. and R.T.Q.H.-C.; writing—original draft preparation, J.C.C.-H. and R.T.Q.H.-C.; writing-review and editing, J.C.C.-H., R.T.Q.H.-C., and R.A.-V.; visualization, A.H.-J. and H.M.-C., and S.O.-S.; supervision, J.C.C.-H. All authors have read and agreed to the published version of the manuscript.

Funding: This research received no external funding.

Data Availability Statement: The data presented in this study are available on request from the corresponding author.

Conflicts of Interest: The authors declare no conflict of interest.

\section{References}

1. Migeon, A.; Dorkeld, F. Spider Mites Web: A Comprehensive Database for the Tetranychidae. Available online: http://www1 .montpellier.inra.fr/CBGP/spmweb (accessed on 5 January 2021).

2. Zhang, Z.Q. Mites of Greenhouses: Identification, Biology and Control; CABI Pub: Wallingford, UK, 2003 ; p. 244.

3. Bolland, H.R.; Gutierrez, J.; Flechtmann, C.H.W. World Catalogue of the Spider Mite Family (Acari: Tetranychidae); Brill Academic Publishers: Leiden, The Netherlands, 1998; p. 392. 
4. Humeres, E.C.; Morse, J.G. Baseline susceptibility of persea mite (Acari: Tetranychidae) to abamectin and milbemectin in avocado groves in Southern California. Exp. Appl. Acarol. 2005, 36, 51-59. [CrossRef] [PubMed]

5. Cerna, E.; Badii, M.H.; Ochoa, Y.; Aguirre, L.A.; Landeros, J. Life table of Oligonychus punicae Hirst (Acari: Tetranychidae) in avocado leaves (Persea americana Mill) in the hass, fuerte and criollo cultivars. Univ. Cienc. 2009, 25, 133-140.

6. Fathipour, Y.; Maleknia, B. Mites Predator. In Ecofriendly Pest Management for Food Security; Omkar, Ed.; Elsevier: London, UK, 2016; pp. 329-366.

7. Leone, A.; Spada, A.; Battezzati, A.; Schiraldi, A.; Aristil, J.; Bertoli, D. Cultivation, genetic, ethnopharmacology, phytochemistry and pharmacology of Moringa oleifera leaves: An overview. Int. J. Mol. Sci. 2015, 16, 2791. [CrossRef]

8. Anita, S.; Sujatha, P.; Prabhudas, P. Efficacy of pulverized leaves of Annona squamosa (L.), Moringa oleifera (Lam.), and Eucalyptus globulus (Labill.) against the stored grain pest, Tribolium castaneum (Herbst.). Recent Res. Sci. Technol. 2012, 4, $19-23$.

9. Moawad, S.S.; Sadek, H.E. Evaluation of two eco-friendly botanical oils on cotton leafworm, Spodoptera littoralis (Boisd) (Lepidoptera/Noctuidae). AOAS 2018, 63, 141-144. [CrossRef]

10. Kamel, A.M. Can we use moringa oil as a botanical insecticide against Spodoptera frugiperda? Acad. J. Entomol. 2010, 3, 59-64.

11. Agra-Neto, A.C.; Napoleão, T.H.; Pontual, E.V.; Santos, N.D.; de Luz, L.A.; de Oliveira, C.M.; de Melo-Santos, M.A.; Coelho, L.C.; Navarro, D.M.; Paiva, P.M. Effect of Moringa oleifera lectins on survival and enzyme activities of Aedes aegypti larvae susceptible and resistant to organophosphate. Parasitol. Res. 2014, 113, 175-184. [CrossRef]

12. Martinez, D.S.T.; Freire, M.G.M.; Mazzafera, P.; Araujo-Júnior, R.T.; Bueno, R.D.; Macedo, M.L.R. Insecticidal effect of labramin, a lectin-like protein isolated from seeds of the beach apricot tree, Labramia bojeri, on the Mediterranean flour moth, Ephestia kuehniella. J. Insect Sci. 2012, 12, 62. [CrossRef]

13. Chacón-Hernández, J.C.; Monjarás-Barrera, J.I.; Mora-Olivo, A.; Vanoye-Eligio, V.; Rosas-Mejía, M.; Reyes-Zepeda, F. Two New Hosts of Oligonychus punicae (Acari: Tetranychidae) in Northeastern Mexico: Trichilia havanensis (Meliaceae) and Pithecellobium dulce (Fabaceae). J. Entomol. Sci. 2020, 55, 286-287. [CrossRef]

14. Castillo, F.; Gallegos, G.; Mendez, M.; Rodríguez, R.; Reyes, A.; Aguilar, C. In vitro antifungal activity of plant extracts obtained with alternative organic solvents against Rhizoctonia solani Kühn. Ind. Crop Prod. 2010, 32, 324-328. [CrossRef]

15. Shami, A.M.M.; Philip, K.; Muniady, S. Synergy of antibacterial and antioxidant activities from crude extracts and peptides of selected plant mixture. BMC Complementary Altern. Med. 2013, 13, 360. [CrossRef] [PubMed]

16. Kuklinski, C. Farmacognosia: Estudio de las Drogas y Sustancias Medicamentosas de Origen Natural; Omega: Barcelona, España, 2000; p. 528.

17. Tiwari, P.; Kumar, B.; Kaur, M.; Kaur, G.; Kaur, H. Phytochemical screening and extraction: A Review. IPS 2011, 1, 98-106.

18. Mujeeb, F.; Bajpai, P.; Pathak, N. Phytochemical evaluation, antimicrobial activity, and determination of bioactive components from leaves of Aegle marmelos. BioMed Res. Int. 2014, 497606. [CrossRef]

19. Ahmadi, A. Demographic toxicology as a method for studying the dicofol-twospotted spider mite (Acari: Tetranychidae) system. J. Econ. Entomol. 1983, 76, 239-242. [CrossRef]

20. Vásquez, C.; Aponte, O.; Morales, J.; Sanabria, M.E.; García, G. Biological studies of Oligonychus punicae (Acari: Tetranychidae) on grapevine cultivars. Exp. Appl. Acarol. 2008, 45, 59-69. [CrossRef] [PubMed]

21. Abbott, W.S. A method of computing the effectiveness of an insecticide. J. Econ. Entomol. 1925, 18, 265-267. [CrossRef]

22. Kramer, W.L.; Mulla, S. Oviposition attractants and repellents of mosquitoes: Oviposition responses of Culex 1 mosquitoes to organic infusions. Environ. Entomol. 1979, 8, 1111-1117. [CrossRef]

23. Hussey, N.W.; Parr, W.J. The effect of glasshouse red spider mite (Tetranychus urticae Koch) on the yield of cucumbers. J. Hortic. Sci. 1963, 38, 255-263. [CrossRef]

24. Nachman, G.; Zemek, R. Interactions in a tritrophic acarine predator-prey metapopulation system III: Effects of Tetranychus urticae (Acari: Tetranychidae) on host plant condition. Exp. Appl. Acarol. 2002, 26, 27-42. [CrossRef]

25. Montelongo-Ruíz, G.; Chacón-Hernández, J.C.; Reyes-Zepeda, F.; Octavio-Aguilar, P.; Heinz-Castro, R.T.Q.; Juárez, L.; OrdazSilva, S. The stimulatory effect of Chamaedorea radicalis ethanolic extract on Tetranychus merganser Boudreaux (Acari: Tetranychidae). Int. J. Acarol. 2020, 46, 318-321. [CrossRef]

26. Marčić, D.; Međo, I. Acaricidal activity and sublethal effects of an oxymatrine-based biopesticide on two-spotted spider mite (Acari: Tetranychidae). Exp. Appl. Acarol. 2014, 64, 375-391. [CrossRef] [PubMed]

27. Marčić, D.; Međo, I. Sublethal effects of azadirachtin-A (NeemAzal-T/S) on Tetranychus urticae (Acari: Tetranychidae). Syst. Appl. Acarol. 2015, 20, 25-38.

28. Finney, D.J. Probit Analysis, 3rd ed.; Cambridge University Press: Cambridge, UK, 1971; p. 331.

29. SAS Institute. SAS/STAT 9.1: User's Guide; SAS Institute Inc.: Cary, NC, USA, 2002; pp. 3703-3796.

30. Sarmah, M.; Rahman, A.; Phukan, A.K.; Gurusubramanian, G. Effect of aqueous plant extracts on tea red spider mite, Oligonychus coffeae, Nietner (Tetranychidae: Acarina) and Stethorus gilvifrons Mulsant. Afr. J. Biotechnol. 2009, 8, 417-423.

31. Roy, S.; Handique, G.; Muraleedharan, N.; Dashora, K.; Mukhopadhyay-Roy, S.; Mukhopadhyay, A.; Babu, A. Use of plant extracts for tea pest management in India. Appl. Microbiol. Biotechnol. 2016, 100, 4831-4844. [CrossRef] [PubMed]

32. Hikal, W.M.; Baeshen, R.S.; Said-Al Ahl, H.A.H. Botanical insecticide as simple extractives for pest control. Cogent Biol. 2017, 3, 1404274. [CrossRef]

33. Roy, S.; Gurusubramanian, G.; Nachimuthu, S.K. Anti-mite activity of Polygonum hydropiper L. (Polygonaceae) extracts against tea red spider mite, Oligonychus coffeae Nietner (Tetranychidae: Acarina). Int. J. Acarol. 2011, 37, 561-566. [CrossRef] 
34. Fetoh, B.E.A.; Al-Shammery, K.A. Acaricidal ovicial and repellent activities of some plant extracts on the date palm dust mite, Oligonychus afrasiaticus Meg. (Acari: Tetranychidae). Int. J. Environ. Sci. Eng. 2011, 2, 45-52.

35. Mamun, M.S.; Hoque, M.M.; Ahmed, M.; Sarkar, A.; Kabir, H. Evaluation of some indigenous plant extracts against red spider mite, Oligonychus coffeae Nietner (Acari: Tetranychydae) in tea. Persian J. Acarol. 2015, 4, 425-435. [CrossRef]

36. Roobakkumar, A.; Subramaniam, M.S.R.; Babu, A.; Muraleedharan, N. Bioefficacy of certain plant extracts against the red spider mite, Oligonychus coffeae (Nietner) (Acarina: Tetranychidae) infesting tea in Tamil Nadu, India. Int. J. Acarol. 2010, 36, 255-258. [CrossRef]

37. Roy, S.; Mukhopadhyay, A. Bioefficacy assessment of Melia azedarach (L.) seed extract on tea red spider mite, Oligonychus coffeae (Nietner) (Acari: Tetranychidae). Int. J. Acarol. 2012, 38, 79-86. [CrossRef]

38. Dimetry, N.Z.; El-Gengaihi, S.; Reda, A.S.; Amer, S.A.A. Toxicity of some compounds isolated from Abrus precatorius L. seeds towards the two-spotted spider mite Tetranychus urticae Koch. Acarologia 1990, 31, 361-366.

39. Dimetry, N.Z.; Amer, S.A.A.; El-Gengaihi, S. Toxicological evaluation and biological potency of petroleum ether extract of two plants and their isolates towards the two spotted spider mite "Tetranychus urticae" Koch. Acarologia 2003, 43, 67-73.

40. Hosny, A.H.; Keratum, A.Y.; Hasan, N.E. Comparative efficiency of pesticides and some predators to control spider mites: IIBiological and behavioral characteristics of predators Stethorus gilvifrons, Amblyseius gossipi and Phytoseiulus macropili and their host two spotted spider mite, Tetranychus urticae under some chemicals treatments. J. Plant Prot. Path. Mansoura Univ. 2010, 1, 1065-1085.

41. El-Wakeil, N.E. Botanical pesticides and their mode of action. Gesunde Pflanzen 2013, 65, 125-149. [CrossRef] 